\title{
THE URGENCY ON DESIGNING THE LEGISLATION FOR THE USE OF ARTIFICIAL INTELLIGENCE IN INDONESIAN MEDICAL PRACTICE
}

\author{
*Hary Abdul Hakim, *Chrisna Bagus Edhita Praja, **Hardianto Djanggih \\ *Fakultas Hukum, Universitas Muhammadiyah Magelang, Jawa Tengah, \\ **Fakultas Hukum, Universitas Muslim Indonesia, Makassar, Sulawesi Selatan. \\ Corresponding author. Email: harvabdulhakim@unimma.ac.id
}

Paper received on: 17-09-2021 ; Revised on: 08-12-2021 ; Approved to be published on: 14-12-2021;

DOI: http://dx.doi.org/10.30641/deiure.2021.V21.541-550

\begin{abstract}
Artificial intelligence (AI) offers the potential for a great improvement in patient care, both in diagnose and disease treatment, and a consequential reduction in healthcare costs, a part of opportunities and challenge are ahead. The use of AI in medicine was significantly developed in some countries. Indonesia as a modern country also has a great change in promoting the use of AI. The study aims to propose on designing the legislation for the use of AI in Indonesian medical practices. The method used in this research is normative juridical approaches-with descriptive analysis. The data used are primary legal material namely the Indonesian Penal Code and Law No. 36 of 2009 on Health Law. Meanwhile, the secondary legal material used are books, journals, and other legal documents. The results show that designing the new legislation as the guidance and basis for the use of AI shall give a good impact on the development of health services as practices among other countries. Moreover, Health Act 2009 clearly supported the use of advance technology's product in medicine. Yet, the application of AI facilitates interpretation follows with high accuracy and speed for medical diagnoses.
\end{abstract}

Keywords: Artificial Intelligence; Health Care Services; Technology; Health Law

\section{INTRODUCTION}

Artificial intelligence (AI) offers the potential for great improvement including in the area of patient care and gave a consequential reduction in healthcare costs. From The huge number of growing populations in Indonesia are expected to further fuel the demand for healthcare. Meanwhile, future Indonesian healthcare sector needs to look for innovative solutions to figure out how to be more effective and efficient without spending excessively. This is where technology comes in, through the rapid developments in technology. Particularly, in the fields of AI and robotics can help supplement the healthcare industry. As well In 1955, John McCarthy coined the "artificial intelligence," which is defined as "the science and engineering of creating intelligent machines". Furthermore, in 1956, at a Dartmouth College conference on artificial intelligence launched the field of AI. Rapid development of AI, regarded as a discipline of engineering, employs fresh thoughts and techniques to solve complex problems. Computers may one day be as intelligent as humans, supported by the advancements in electronic speed, capacity, and software development.1

Nowadays, AI in medicine and health care has been a part of world issues. Furthermore, the use of AI in medicine may be applied into several functions over diagnosis and treatment. Recently, AI techniques have sent vast waves across healthcare even fueling an active discussion of whether AI doctors will eventually replace human physicians in the future. Although scholars argued that human physicians will not be replaced by machines in the foreseeable future, AI can definitely assist physicians to make better clinical decisions or even replace human judgment in certain functional areas of healthcare. ${ }^{2}$

Pavel Hamet and Johanne Tremblay, "Artificial Intelligence in Medicine," Metabolism: Clinical and Experimental 69 (2017): S36-S40, http://dx.doi. org/10.1016/j.metabol.2017.01.011.

2 The Asean Post Team, "The Potential of Digital Healthcare," The Asean Post, last modified 2018, accessed April 26, 2021, https://theaseanpost.com/ article/potential-digital-healthcare. 
These new technologies are utilized more efficiently in medical care delivery. ${ }^{3}$ AI's future in healthcare is not exclusively optimistic since there are disadvantages in the process. Numerous questions arise whether AI can perform the rights and obligation of doctor, protecting privacy issue and yet the applicable law has not entirely ready with these advances. ${ }^{4}$

The used of AI into healthcare system in Indonesia indicates supported by the current regulation. It is proved that Health Act 2009 Article 42 and 44 explains that the technology and health technology product can be developed and applied for medical care.

Recently, In Indonesia, the function of AI is still limited to detection and monitoring. Although, the use of AI in health practice in Indonesia can be found in radiological examinations, for example Magnetic Resonance Imaging (MRI). A Machine Learning (ML) Model System using imaging or ECG data can already be used to predict coronary heart disease which will help to prevent unnecessary cardiac catheterization and referral for acute coronary syndromes, better detect arrhythmias and ECG abnormalities which is more subtle.

During the Covid-19 outbreak, Indonesian telemedicine begun to reduce the spread the corona virus disease. Telemedicine enabled the information technology and telecommunications to be used to transfer medical information, diagnosis, therapy, and education. ${ }^{5}$

This article briefly describes the concept of AI in healthcare services, including several possible applications, then considers its legal implications in four areas of law: regulation, tort, and privacy.

\footnotetext{
3 McCree Lake, "Artificial Intelligence Gives HR an Opportunity to Transform the Enterprise," last modified 2018, accessed May 20, 2021 https://www.cio. com/article/326345o/artificial-intelligence-gives-hran-opportunity-to-transform-the-enterprise.html.

4 Amanda Swanson and Fazal Khan, "The Legal Challenge of Incorporating Artificial Intelligence into Medical Practice," 6 J. Health E Life Sci. L (2012).

5 Douglas Perednia and Ace Allen, "Telemedicine Technology and Clinical Applications," JAMA The Journal of the American Medical Association 273, no. 6 (1995): 483-8.
}

\section{RESEARCH METHOD}

. The research method used in this research is normative juridical with statute approach. By reviewing laws and regulations related to the problems that are the subject of discussion. The data were collected through the library research, consisting of primary legal materials such as legislation and secondary legal materials as well as scientific works, journals, or books and other related documents. The data were analyzed using a descriptive method by explaining the problem statement in the form of paragraphs.

\section{RESULT AND DISCUSSION}

\section{A. The uses of AI in healthcare services}

Technological innovations have impacted almost every aspect of life over the past century. The concept of artificial intelligence is not new but has recently come into view as a technology that is capable of revolutionizing the world and bringing a new industrial revolution. A significant amount of research and discussion among scientists has focused on the critical topic of potential productivity gains from $\mathrm{AI}$. AI is rapidly moving to change the global issues, also when AI would be used in most of the jobs, and healthcare is a part of this moving. Even today, computers, and machines are used in every activity of life. Advanced applications of technology featuring machine learning and AI have greatly affected the medical industry of healthcare including hospitals and insurance companies. AI system for healthcare has the potential mechanism to diagnose and treatment of diseases such as a doctor to ensure that patients get the right treatment at the right time. In healthcare, AI relies on the power of computers to shift through and make sense of massive electronic data about the patients.

AI aims to mimic human cognitive functions. It is bringing a paradigm shift to healthcare, powered by increasing availability of healthcare data and rapid progress of analytics techniques. AI can be applied to various types of healthcare including structured and unstructured. AI was popular techniques including machine for neural network. ${ }^{6}$ Major disease areas that use AI include cancer, neurology, and cardiology. More details of the AI applications in stroke, in the three major

\footnotetext{
6 Fei Jiang et al., "Artificial Intelligence in Healthcare: Past, Present and Future," Stroke and Vascular Neurology 2, no. 4 (2017): 230-243.
} 
areas of early detection and diagnosis treatment as well as outcome prediction.

Artificial intelligence in medicine can and is being used to manage records and miscellaneous data. AI can be used to re-format, trace, and store data which will provide faster access. ${ }^{7}$

This type of data management is one of the most widespread uses of AI in healthcare. The main advantages of AI to analyse data, things like reports and notes of a patients file, clinical expertise, and externally conducted research can be analysed by AI to select the best way to treat a patient. This can open up opportunities for adjusted treatments for individuals which might have been difficult in the past due to insufficient data management.

Using AI for medical services is one of the medical challenges. Medical service in Japan is already using AI to give medical diagnostic services. $\mathrm{AI}$ is the new innovation to give best services and efficient treatment to the patient, where the medical practices have been slow on giving diagnostic for the patient. The use of AI will help the medical practices to be faster to give the diagnostic for the patient. The private Showa University in Tokyo together with Nagoya University and Cyber net Systems Co. have jointly developed software which can analyses, give diagnosis and treatment of diseases. ${ }^{8}$

Similarly, countries across Asia Pacific (APAC) could stand to take a note of Japan's plans to establish 10 artificial intelligence (AI)-based hospitals by 2022 with an investment of more than $\$ 100 \mathrm{~m}$ as part of its efforts to revolutionize the country's healthcare system, based on a report by data and analytics firm Global Data. The country has earmarked healthcare as one of its priority sectors under the strategy, one of its key focuses lies in improving the quality and productivity of nursing care by using technologies such as robots and sensors. In addition, it aims to provide diagnosis support and innovative new drugs by

\footnotetext{
7 Craig Ellis, "Artificial Intelligence in Health Care," last modified 2019, accessed May 1, 2020, https:// www.getreferd.com/blog/artificial-intelligence-inhealthcare/.

8 Kyodo, "AI-Based Medical Diagnostic Services Set to Debut in Japan," The Japan Times, last modified 2019, accessed January 9, 2021, https://www.japantimes. co.jp/news/2019/o2/o4/national/science-health/aibased-medical-diagnostic-services-set-debut-japan/.
}

using big data, on top of providing personalized healthcare services by leveraging on the Internet of Things (IoT).

Furthermore, not only in Japan, Medicare program in the United States also uses AI for their medical services. An artificial intelligence company owned by Google, teamed with Britain's National Health Service in 2016 to build a smartphone application to alert patients at risk for kidney failure. Today, the AI-focused company is working with several NHS research hospitals, applying analytics across huge swaths of anonym zed patient data to better understand disease and effective treatment methods.

PTC Inc. is a global computer software company. Founded in 1985, the Boston Company became an IoT pioneer. There is real progress being made in healthcare. Additionally, the Medicare program in the United States will begin paying doctors on the basis of quality of care, rather than visits. This will incentivize healthcare organizations to invest in systems of sensors, patients, caregivers and software. The result should be more sensors and more virtual care.

Fast forward to 2030, and Indonesian's health and healthcare look different from today for the whole patient journey from identifying health concerns to diagnosis, treatment, and posttreatment coordinated care. ${ }^{9}$ The idealized 2030 vision is described is far from today's reality. As Indonesia designs a blueprint for a healthcare ecosystem for the new era, it will need to manage the triple aims of high quality, low cost, and greater patient access. As it does this, Indonesian medical law also takes a part as particular priority to implement AI for Indonesian's health and healthcare which will need the standard operational procedures and it must be regulated in the Medical Law.

In Indonesia, the regulations regarding technology used in the health sector have been regulated in Health Act 2009 in article 42:

a. Technology and health technology products shall be held, researched, circulated, developed, and utilized for public health; and

\footnotetext{
9 Oliver Wyman, "The Future of the Indonesian Healthcare Ecosystem" (Marsh \& McLennan Companies, 2018), accessed May 20, 2021, https:// www.oliverwyman.com/content/dam/oliver-wyman/ $\mathrm{v} 2 /$ publications/2018/october/the-future-of-theindonesian-healthcare-ecosystem.pdf.
} 
b. Health technology includes all methods and tools used to prevent disease, detect disease, alleviate suffering from illness, cure, minimize complications, and restore health after illness.

Basically, the use of technology in Indonesia in the health sector has been permitted by law to improve public health services. It can bridge AI to enter into one of the technologies that are owned to develop and assist the health system in the society. AI can be one of the highest efficient technologies because it is able to work systematically the and results obtained will be more optimal and sufficient. ${ }^{10}$

The development of AI technology must be maximized in the health sector in Indonesia because in the future AI will develop very rapidly including in the health sector. Experiments in the health sector using technology have also been regulated in article 44:

a. In developing technology, testing of technology or technological products can be carried out on humans or animals;

b. The experiment shall be carried out with the guarantee of not harming the human being used as the subject; and

c. The experiment shall be carried out by an authorized person and with the approval of the person being tested

The use of AI in medical practices in Indonesia can be found en-in the cardiovascular field. Currently, it has a very broad development potential, including predicting the prognosis and mortality outcomes of heart failure patients with normal ejection fractions, and predicting heart failure faster than clinicians alone.

In the near future, artificial intelligence techniques will increasingly play a vital role in the practice of precision cardiovascular medicine in many ways:

a. Identify previously unknown risk factors;

b. Analysis of images/results of supporting examinations, both simple and currently used such as ECG, to analysis of more

1o Mayanda Mega Santoni, Nurul Chamidah, and Nurhafifah Matondang, "Prediksi Hipertensi Menggunakan Decision Tree, Naïve Bayes Dan Artificial Neural Network Pada Software KNIME," Techno.Com 19, no. 4 (2020): 353-363. complex examinations such as results of echocardiography, CT scan, or MRI;

c. Changing diagnostic criteria; and

d. Determine therapeutic decisions tailored selection/tailored to patients. ${ }^{11}$

Furthermore, the use of long-distance health services or telemedicine is one of the health service strategy efforts in dealing with the COVID-19 Pandemic in Indonesia. As recommended by the World Health Organization (WHO), telemedicine is an effort to provide remote care services by all health professionals with the help of information equipment and communication technology in the exchange of information, treatment, prevention of disease and injury, research and evaluation.

Practically, Telemedicine services in Indonesia have existed for a long time, which was introduced by the Ministry of Health in 2012. ${ }^{12}$

However, apart from the benefits provided in implementing $\mathrm{AI}$ in Indonesia, there are things that need to be considered, especially the consequences of the failure of AI. Moreover, the consequences of the failure do not have relevant provision on its penalty. When an act of malpractice occurs as is common in medical practice, it is necessary to regulate the legal liability. Then, in the implementation of AI within the medical practices, it shall be followed by designing the relevant regulation to give the legal certainty.

\section{B. The challenges of implementing AI \\ 1. The need of human resources}

Human Resource is the most challenging problem that will be faced while implementing AI in medical practice. Human is the subject that will work together with $\mathrm{AI}$ and robots. AI, as well as the new technology innovation, is designed to help human activities. When AI is implemented in medical practice, AI will help to solve various Human Resource problems. Human Resource challenges in medical practitioners at

"dr. Alexandra Francesca Chandra, "The Role of Artificial Intelligence in Cardiovascular Medicine," Alomedika, accessed December 8, 2021, https://www. alomedika.com/peran-artificial-intelligence-dalamkedokteran-kardiovaskular.

12 Salesika, Rico Januar Sitorus, and Rizma Adlia Syakurah, "Penggunaan Telemedicine Sebagai Teknologi Informasi Dalam Rangka Solusi Alternatif Pencegahan Penyebaran COVID-19: Literature Review," MPPKI The Indonesian Journal of Health Promotion 4, no. 4 (2021): 448-455. 
least will face three major issues: doctor shortages worldwide, the aging and burnout of physicians and a higher demand of chronic care. An effective system depends on quality of its health workers. ${ }^{13}$ It is estimated that the need-based shortage of medical practitioners globally is about 17.4 million, and the aging of medical practitioners is an additional challenge. ${ }^{14}$

The human resource is widening across the globe, and it is obvious that without a capable medical practitioner, there is no way to provide quality care. Using the disruptive technologies in healthcare will help to solve various human resource problems. ${ }^{15}$ Witth The good quality of medical practitioners will increase the quality of treatment provision. Using AI as the "cognitive assistant" that is capable of analysis and reasoning and a range of clinical knowledge will help Medical Practitioners in doing their job. AI as an assistant would be able to analyse radiology images to detect medical issues. ${ }^{16}$

If Medical Practitioners can operate the AI properly, AI-based services could facilitate more accurate diagnoses, administration, and decision making and big data analytics. Using the AI could also offer solutions to improve the access to care. However, AI does not cover the whole process of treatment: empathy, proper communication and the human touch are still equally essential. No application or device can replace personal connection and trust. ${ }^{17}$

${ }^{13}$ James Campbell et al., A Universal Truth: No Health without a Workforce, World Health Organization (Geneva, 2013), accessed April 20, 2021, http://www. who.int/workforcealliance/knowledge/resources/ hrhreport2013/en/.

14 Human Resources, Health Workforce Requirements for Universal Health Coverage and the Sustainable Development Goals (Geneva, 2016), accessed May 20, 2021, https://apps.who.int/iris/bitstream/hand le/10665/250330/9789241511407-eng.pdf.

15 Yudo Devianto and Saruni Dwiasnati, "Kerangka Kerja Sistem Kecerdasan Buatan Dalam Meningkatkan Kompetensi Sumber Daya Manusia Indonesia," Jurnal Telekomunikasi dan Komputer 10, no. 1 (2020): 19-24.

16 A Y Hiadayat and A S Purnomo, "Sistem Pakar Diagnosis Gejala Penyakit Turbekulosis Dengan Metode Dempster-Shafer; Studi Kasus: UPTD Puskesmas," KONSTELASI: Konvergensi Teknologi Dan Sistem Informasi 1, no. 2 (2021): 442-453, https:// ojs.uajy.ac.id/index.php/konstelasi/article/view/4263.

${ }_{17}$ World Health Organization and The World Bank, Tracking Universal Health Coverage - First Global Monitoring Report, 2015.
The role of the human physician is inevitable, but AI could be a very useful cognitive assistant. $\mathrm{AI}$ also means a paradigm shift in the doctorpatient relationship, as digital health transforms the well-known doctor-patient hierarchy into an equal-level partnership. ${ }^{18}$ Furthermore, to implementing AI models in medical practice is a challenge. But, a much bigger challenge is the medical practitioner who has interaction directly with the robot and AI. Trying together to work with $\mathrm{AI}$ in the healthcare space or medical practice will raise some risk, two major problems due to the risk of using $\mathrm{AI}$ in health care system are: Hackers are outside intruders, while negligent insiders are healthcare personnel who inappropriately access and use healthcare data. ${ }^{19}$

\section{Technological advancement}

Automation could be labelled differently, maybe healthcare data technologies or even AI. Labels, however, must not obscure the core healthcare Automation proposition. Historically, humans have entered into symbiotic intimate relationships with those with more (or more perceived) knowledge or expertise. ${ }^{20}$ One of the problems with the use of $\mathrm{AI}$ in the health sector is a technological problem. The use of AI basically must be operated and supervised by someone who is an expert in the field of technology and health. AI operations must be monitored by someone who understands health so inputting data and followup of health practices can be followed up properly.

The latest techniques in AI making use of deep neural networks have reached amazing performance in the last five to seven years. However, the tooling and infrastructure needed to support these techniques are still immature, and only few people have the necessary technical competence to deal with the whole range of data and software engineering issues. Especially in medicine, AI solutions will often face problems

18 Mikael Huss, "Challenges of Implementing AI in Healthcare," Peltarion, last modified 2018, accessed June 25, 2021, https://peltarion.com/blog/ data-science/challenges-of-implementing-ai-inhealthcare.

19 Ida Lucente, "Tackling Privacy and Security When Building AI in Healthcare," DZone, last modified 2018, accessed May 4, 2021, https://dzone.com/articles/ tackling-privacy-and-security-when-building-ai-in.

2o Nicolas Terry, "Appification, AI, and Healthcare's New Iron Triangle," Journal of Health Care Law E Policy 20 (2017): 117-182. 
related to limited data and variable data quality. Predictive models will need to be retrained when new data comes in, keeping a close eye on changes in data-generation practices and other real-world issues that may cause the data distributions to drift over time. If several data sources are used to train models, additional types of "data dependencies," which are seldom documented or explicitly handled, are introduced.

In medical applications, transfer learning - using a pre-trained model and adapting it to one's specific use case - is often applied, but then a "model dependency" is introduced where the underlying model may need to be retrained or change its configuration over time. The large amount of "glue code" typically needed to hold together an AI solution, together with potential model and data dependencies, making it very difficult to perform integration tests on the whole system and make sure that the solution is working properly at any given time.

Behind the AI problem to be applied technologically in Indonesia, there are several advantages in using AI for health purposes. A McKinsey Global Institute publication stated that AI in healthcare could lead to quicker diagnoses, better treatment plans, and improved health insurance. The use of AI in the health sector will further speed up the process of diagnosing someone when indicated by certain diseases. Moreover, Electronic medical records, patient portals, digitized medical devices, and even wearable devices are becoming more broadly used. These systems have been largely transactional, AI systems as machine learning go beyond replacing human action to analyse data, make decisions, and exercise judgment

\section{Legal liability enforcement as the consequences of $\mathrm{AI}$ fault}

In accordance with the principle of equality before the law, every citizen involved in a criminal act may be subjected to criminal prosecution and this includes doctor. However, a criminal act alone is not sufficient to establish criminal liability. Using AI is relatively simple. If there is a system that takes action that causes crime or if there is an obligation, criminal action will occur again. ${ }^{21}$

\footnotetext{
${ }^{21}$ Gabriel Hallevy, "The Criminal Liability of Artificial Intelligence Entities - from Science Fiction to Legal Social Control," Akron Intellectual Property Journal 4,
}

It must be accompanied with criminal state of mind - the mens rea. The issue of mens rea has become the subject of debate within the realm of medical malpractice litigation since it is believed that no doctor will intentionally inflict harms upon his patient. ${ }^{22}$ According to the Indonesian legal system, only conduct which has been defined as a criminal offence under a penal code or other criminal legislations will result in criminal prosecutions. Following the principle of nullum delictum nulla poena sine praevia lege poenali. The law upon which the prosecution will be based must have been existed prior to the law and it cannot be applied retroactively.

Furthermore, the Indonesian penal code acknowledges negligence as a form of mens rea besides criminal intent (opzet). As a result, under Indonesian criminal law, a criminal offense (delik) might theoretically be separated into two categories based on the nature of the mens rea: delik dolus and delik colpus. The former refers to any intentional crime, whereas the latter refers to any crime committed as a result of a negligent action. The criminal attempt goes right to the heart of criminal culpability. ${ }^{23}$

Criminal prosecution of doctors has been regulated in Indonesia since early times. There are some offences under the Indonesian Penal Code which relate to medical practitioners. These include:

a. Issuing false health information letter. Section 267 prohibits a doctor from issuing a false health information letter regarding the existence or absence of a particular disease. It will be subject to a maximum of eight years of imprisonment;

b. Committing indecency against the patient. Section 294 (2) prohibits several parties including a doctor from committing indecency against person under their care. It will be subject to a maximum of seven years of imprisonment;

c. Disclosing confidential information. Section 322 prohibits any person from disclosing

no. 2 (2010): 171-199.

22 Muh Endriyo Susila, "Criminal Prosecution of Doctors in Indonesia: Issues and Problems," IIUM Law Journal 23, no. December 2015 (2015): 439-458.

${ }^{23}$ Jerome Hall, "Criminal Attempt. A Study of Foundations of Criminal Liability," The Yale Law Journal 49, no. 5 (1940): 789-840. 
confidential information which the law requires him to protect. It will be subject to a maximum of nine months of imprisonment;

d. Euthanasia. Section 344 prohibits a doctor from terminating his patient's life as required by the patient himself for ending his suffering commonly known as mercy killing or euthanasia. It will be subject to a maximum of twelve years of imprisonment;

e. Being involved in illegal abortion. Section 348 (1) prohibits any person from being involved in illegal abortion. It will be subject to a maximum of five years and six months of imprisonment. If the abortion has caused the death of the pregnant woman, based on section 348 (2), the maximum punishment is fifteen years of imprisonment.

Besides the above provisions, there are several other provisions under the Indonesian Penal Code which are also applicable to doctors, such as:

a. Section 351 on maltreatment. According to this provision, it is punishable with a maximum of two years and eight months of imprisonment. This law is applicable for doctors who exercise medical treatment without their patient's consent;

b. Section 359 on negligence which result in death. According to this provision, any person who has negligently caused death on others is subject to a maximum of five years of imprisonment. This law applies to doctors who cause the death of their patients due to negligence; and

c. Section 360 on negligence which results in injury. According to this provision, any person who has negligently caused serious injury on others is subject to a maximum of five years of imprisonment. This law applies to doctors who inflict injury on their patients due to negligence

The problem is whether AI can be a legal subject to get criminal liability, because in-the criminal system applied by Indonesia only has two legal subjects, namely person and legal person. Implementing AI as one of the technologies for the development of the health system in Indonesia will face one of the tough challenges of AI being a legal subject that can be charged with criminal liability. In the development of AI, it allows AI to take actions against the law as subjected by criminal liability.

\section{CONCLUSION}

Previous discussion mentioned on the use of AI in medical practices, while during its implementation Indonesia faced various significant challenges. Meanwhile, by implementing AI in medicine, Indonesia will have significant good impact especially the future health care services. Furthermore, by the current existing regulation, namely Health Act 2009, states that any development of technology in health care services is allowed. By implementing AI, it is easier for medical professionals to care for a larger number of patients. AI tools help them make better diagnostic decisions, improve treatment outcomes and reduce medical errors. AI could also take part in solving Human Resource issues, such as recruiting and selecting the potential healthcare work force. However, to avoid the misconduct of AI in medicine, and to face various challenges ahead in its implementation such as: human resources challenges, technology challenges and legal liability challenges. In conclusion, the application of AI in medical practice must be accompanied by the establishment of regulations, which aim to avoid all actions or negative impacts arising from the application of AI.

\section{BIBLIOGRAPHY}

Campbell, James, G Dussault, J Buchan, F PozoMartin, M Guerra Arias, C Leone, A Siyam, and A Cornetto. A Universal Truth: No Health without a Workforce. World Health Organization. Geneva, 2013. http://www. who.int/workforcealliance/knowledge/ resources/hrhreport2013/en/.

Devianto, Yudo, and Saruni Dwiasnati. "Kerangka Kerja Sistem Kecerdasan Buatan Dalam Meningkatkan Kompetensi Sumber Daya Manusia Indonesia." Jurnal Telekomunikasi dan Komputer 10, no. 1 (2020): 19-24.

dr. Alexandra Francesca Chandra. "The Role of Artificial Intelligence in Cardiovascular Medicine." Alomedika. Accessed December 8, 2021. https://www.alomedika.com/peranartificial-intelligence-dalam-kedokterankardiovaskular. 
Ellis, Craig. "Artificial Intelligence in Health Care." Last modified 2019. Accessed May 1, 2020. https://www.getreferd.com/blog/ artificial-intelligence-in-healthcare/.

Hall, Jerome. "Criminal Attempt. A Study of Foundations of Criminal Liability." The Yale Law Journal 49, no. 5 (1940): 789-840.

Hallevy, Gabriel. "The Criminal Liability of Artificial Intelligence Entities - from Science Fiction to Legal Social Control." Akron Intellectual Property Journal 4, no. 2 (2010): 171-199.

Hamet, Pavel, and Johanne Tremblay. "Artificial Intelligence in Medicine." Metabolism: Clinical and Experimental 69 (2017): S36-S40. http://dx.doi.org/10.1016/j. metabol.2017.01.011.

Hiadayat, A Y, and A S Purnomo. "Sistem Pakar Diagnosis Gejala Penyakit Turbekulosis Dengan Metode Dempster-Shafer ; Studi Kasus : UPTD Puskesmas." KONSTELASI: Konvergensi Teknologi Dan Sistem Informasi 1, no. 2 (2021): 442-453. https:// ojs.uajy.ac.id/index.php/konstelasi/article/ view/4263.

HumanResources.HealthWorkforceRequirements for Universal Health Coverage and the Sustainable Development Goals. Geneva, 2016. https://apps.who.int/iris/bitstream/han dle/10665/250330/9789241511407-eng.pdf.

Huss, Mikael. "Challenges of Implementing AI in Healthcare." Peltarion. Last modified 2018. Accessed June 25, 2021. https://peltarion. $\mathrm{com} / \mathrm{blog} / \mathrm{data}-\mathrm{science} / \mathrm{challenges-of-}$ implementing-ai-in-healthcare.

Jiang, Fei, Yong Jiang, Hui Zhi, Yi Dong, Hao Li, Sufeng Ma, Yilong Wang, Qiang Dong, Haipeng Shen, and Yongjun Wang. "Artificial Intelligence in Healthcare: Past, Present and Future." Stroke and Vascular Neurology 2, no. 4 (2017): 230-243.

Kyodo. "AI-Based Medical Diagnostic Services Set to Debut in Japan." The Japan Times. Last modified 2019. Accessed January 9, 2021. https://www.japantimes.co.jp/ news/2019/02/04/national/science-health/ ai-based-medical-diagnostic-services-setdebut-japan/.
Lake, McCree. "Artificial Intelligence Gives HR an Opportunity to Transform the Enterprise." Last modified 2018. https://www.cio.com/ article/3263450/artificial-intelligencegives-hr-an-opportunity-to-transform-theenterprise.html.

Lucente, Ida. "Tackling Privacy and Security When Building AI in Healthcare." DZone. Last modified 2018. Accessed May 4, 2021. https://dzone.com/articles/tackling-privacyand-security-when-building-ai-in .

Perednia, Douglas, and Ace Allen. "Telemedicine Technology and Clinical Applications." JAMA The Journal of the American Medical Association 273, no. 6 (1995): 483-8.

Salesika, Rico Januar Sitorus, and Rizma Adlia Syakurah. "Penggunaan Telemedicine Sebagai Teknologi Informasi Dalam Rangka Solusi Alternatif Pencegahan Penyebaran COVID-19: Literature Review." MPPKI The Indonesian Journal of Health Promotion 4, no. 4 (2021): 448-455.

Santoni, Mayanda Mega, Nurul Chamidah, and Nurhafifah Matondang. "Prediksi Hipertensi Menggunakan Decision Tree, Naïve Bayes Dan Artificial Neural Network Pada Software KNIME." Techno.Com 19, no. 4 (2020): 353-363.

Susila, Muh Endriyo. "Criminal Prosecution of Doctors in Indonesia: Issues and Problems." IIUM Law Journal 23, no. December 2015 (2015): 439-458.

Swanson, Amanda, and Fazal Khan. "The Legal Challenge of Incorporating Artificial Intelligence into Medical Practice." $6 \mathrm{~J}$. Health \& Life Sci. L (2012).

Terry, Nicolas. "Appification, AI, and Healthcare's New Iron Triangle." Journal of Health Care Law \& Policy 20 (2017): 117-182.

The Asean Post Team. "The Potential of Digital Healthcare." The Asean Post. Last modified 2018. Accessed April 26, 2021. https:// theaseanpost.com/article/potential-digitalhealthcare.

World Health Organization, and The World Bank. Tracking Universal Health Coverage - First Global Monitoring Report, 2015. 
Wyman, Oliver. "The Future of the Indonesian Healthcare Ecosystem." Marsh \& McLennan Companies, 2018. https://www.oliverwyman. $\mathrm{com} / \mathrm{content/dam/oliver-wyman/v2/}$ publications/2018/october/the-future-of-theindonesian-healthcare-ecosystem.pdf. 


\section{HALAMAN KOSONG}

